\title{
Global biomass trade for energy — Part 2: Production and trade streams of wood pellets, liquid biofuels, charcoal, industrial roundwood and emerging energy biomass
}

Svetlana Proskurina ${ }^{\mathrm{a}^{*}}$, Martin Junginger ${ }^{\mathrm{b}}$, Jussi Heinimö ${ }^{\mathrm{c}}$, Beysin Tekinel $^{\mathrm{a}}$ \& Esa Vakkilainen $^{\mathrm{a}}$

${ }^{a}$ Lappeenranta University of Technology, Skinnarilankatu 34, 53850 Lappeenranta, Finland

${ }^{\mathrm{b}}$ Copernicus Institute of Sustainable Development, Heidelberglaan 2, 3584 CS Utrecht, the Netherlands

${ }^{\mathrm{c}}$ Mikkeli Development Miksei Ltd, Sammonkatu 12, 50130 Mikkeli, Finland

*Corresponding author. Tel.: +358466 322953.

E-mail addresses: svetlana.proskurina@lut.fi, proskurina.s@mail.ru (S. Proskurina). Postal address: LUT, P.O. Box 20, FIN-53851 Lappeenranta, Finland.

\begin{abstract}
:
Many countries have limited low-cost biomass resources to satisfy their own demand for bioenergy; consequently, international trade of biomass in various liquid and solid forms is increasing. The aim of this study is to present a quantitative overview of the development of international biomass trade for energy purposes. The paper focuses on the main biomass producing and consuming countries, as well as exporters and importers of liquid and solid biofuels, such as wood pellets, biodiesel and bio-ethanol, and biomass products, for example, industrial roundwood. The study discusses changes in trends that have occurred over the past decade and additionally investigates emerging energy biomass trade streams. Due to increased demand for wood pellets from the heating and industrial sectors, global wood pellet markets and international trade have increased significantly in the past decade. USA and Brazil remain leaders in bio-ethanol production with about $45 \mathrm{Mt}$ and $24 \mathrm{Mt}$ respectively. In recent years, Asian markets such as China (industrial roundwood), South Korea (wood pellets), Malaysia and Indonesia (palm oil) have developed considerably. In the EU-28, more than $60 \%$ of total palm oil consumptions are used for energy purposes. The EU is the global leader in biomass for energy utilisation and also the main importer of most biomass products, particularly wood pellets.
\end{abstract}

Keywords: international biomass trade, bioenergy, biomass market, trade streams, wood pellets, bioethanol, biodiesel, palm oil, industrial roundwood, charcoal 


\section{INTRODUCTION}

Renewable energy sources have grown in importance in the world's energy mix, because of increasing demand for low-carbon energy as a response to climate change, to address environmental concerns such as air pollution emissions, and from a desire to decrease dependence on fossil fuels. ${ }^{1}$ Bioenergy can be used to produce heat, electricity or transport fuels. Bioenergy accounts for approximately $11 \%$ (44.3 EJ) of the world's total primary energy supply. The modern supply of bioenergy is important in the heating sector, where biomass is the largest source of renewable heat. In 2015, in the heating sector, the consumption of bioenergy (mainly solid biomass) was $13.0 \mathrm{EJ}$, which is about $6 \%$ of global heat consumption. As regards electricity generation, total global bioelectricity production was $474 \mathrm{TWh}(1.7 \mathrm{EJ})$ in 2015 , which is approximately $2 \%$ of world electricity generation. In 2015 , biofuels provided $4 \%$ of world road transport fuel demand. ${ }^{2}$

Many countries have limited biomass resources to satisfy their own bioenergy needs, whereas others produce a considerable biomass surplus. Thus, international trade in bioenergy products in the form of solid and liquid fuels has become increasingly important. Wood pellets, biodiesel and bioethanol are examples of widely traded biofuels, particularly in currently expanding markets. Several studies ${ }^{3-8}$ have presented analyses of global trade in biomass, often authored by Task 40 (Sustainable International Bioenergy Trade-Sustainable Biomass Markets and International Trade to support the biobased economy) of the International Energy Agency (IEA) Bioenergy Technology Collaboration Programme. Task 40 focuses on international bioenergy technology potential, bioenergy utilization barriers and trade, as well as their wider implications.

A number of studies have been presented that investigate trade in biomass for energy purposes. In 2007, Heinimö and Junginger ${ }^{3}$ presented a first overview of the global status of production and trade of biomass for energy. Lamers et al. ${ }^{5}$ assess a bottom-up global trade model for analysing future solid and liquid biomass trade. A review of past developments in liquid $^{6}$ and solid ${ }^{7}$ biofuels markets is presented by Lamers et al. Goh et al. ${ }^{8}$ describe the global wood pellets market. Matzenberger et al. ${ }^{9}$ present bioenergy trade models and market scenarios for future perspectives of international bioenergy trade. Goh et al. ${ }^{10}$ investigated the sustainability of traded biomass flows, mostly for the Netherlands. Assessing the international biomass trade for bioenergy in the context of RE deployment scenarios for the EU-27, Hoefnagels et al. ${ }^{11}$ conclude that the share of imported biomass is likely to increase. Work is required that updates and extends the findings of earlier studies.

Indirect trade of biomass for energy, which refers to biomass traded for the manufacture of primary products, such as sawn timber for building construction, rather than bioenergy, but whose by-products are used for energy, was first studied by Heinimö and Junginger ${ }^{3}$ in 2007. Several other studies have also considered indirect trade. For example, Kalt and Kranzl ${ }^{12}$ identify the most relevant indirect trade streams of foreign trade and wood flows for raw wood and wood products within Austria. Trømborg et al. ${ }^{13}$ give an overview of biomass trade for Norway, including indirect trade; and indirect imports of biofuels are studied for Sweden by Ericsson and Nilsson. ${ }^{14}$ The above studies, however, focus mostly on direct trade and specific products, e.g. wood pellets, or specific regions, e.g. the Netherlands, Austria, Norway and the EU. Despite the significant number of studies, there is no comprehensive and up-to- 
date overview of the current state of international biomass trade covering recent developments in the major biomass commodities traded for energy.

This study aims to provide updated figures on production and biomass trade for energy, and the work discusses trends and changes in biomass markets that have occurred over the past decade. Additionally, the study investigates a number of emerging biomass trade streams. The paper is a continuation of a previous paper, which is also presented in this issue, "Global biomass trade for energy - Part 1: statistical and methodological considerations". ${ }^{15}$

\section{METHOD AND DATA COLLECTION}

International biomass trade includes a significant number of cross-border streams. If the entirety of all biomass trade streams, that is, all forest products, agricultural products and biodegradable wastes, were to be investigated until the final end use for energy, the review would become unwieldy and overly complex. Consequently, the study concentrates on only the most significant biomass streams from the bioenergy perspective. The study focuses on trade streams for wood pellets, biodiesel, bio-ethanol, palm oil and charcoal as the most important traded solid and liquid biofuels. Additionally, the study presents trade streams for industrial roundwood as an example of trade in biomass products whose by-products can used for energy purposes. Palm oil and charcoal streams are relatively new in evaluation of international biomass trade for energy and were shown also as an example.

Other biomass products are excluded from the study. For example, wood chips as well as fuelwood and are excluded from the study due to the difficulty of differentiating whether they are traded for energy or other purposes and the relatively small traded volumes. Fuelwood and wood chips are mostly used locally or traded over much shorter distances than, e.g., roundwood. Some crops (e.g. cereals or oils seeds) may be imported for biofuel production. Most agricultural products (other than palm oil) are excluded from our analysis due to lack of resources needed for comprehensive analysis. For similar reasons, trade of waste biomass (i.e. wood waste, municipal solid waste, agricultural residues etc.) is also excluded from this study. Additionally, depending on crop, agricultural products may also partly involve indirect trade. For example, EU agricultural imports are primarily for food, but substantial amounts may end up indirectly as energy ${ }^{1}$. It also can be a subject for future research. Detailed indepth analysis of specific agricultural supply chains from farm gate to final waste utilization and the amount of indirect trade for energy is excluded here to keep the scope of the paper focussed, but could be a topic of interest for future studies. Given the complexity of the processing of the products and assumptions required to determine the amount of indirect trade, this is recommended as subject for future research.

Despite the importance of international trade in biomass and the large amount of research in the area, there is, as yet, no comprehensive unitary database for biomass trade streams. Thus, in this study, the estimated volumes of international biomass trade streams and imports and/or exports of major countries were accessed from literature such as country reports and statistics as well as in consultation with industry experts. This study utilizes data from different statistical sources, ${ }^{16,17}$ but these are based on a few common primary sources such Comtrade. Yearly trade data are mainly based on UN Comtrade, which is the world's largest database of trade statistics and is maintained by the United Nations Statistics Division (UNSD). For

\footnotetext{
${ }^{1}$ e.g. husks, shells, peels etc. from imported agricultural products processed in the EU and used for process heat production or animal manure from meat production based on imported soybeans used to produce biogas
} 
countries that do not report their national trade statistics to UN Comtrade, trade is reconstructed on the basis of data reported by partner countries and missing information is complemented by national and regional sources.

On the global trade figures, trade streams for the EU present approximate evaluation of the intra- trade within EU. In this work, the biomass trade streams are presented in the figures as net trade flows due to the difficulty of estimation of re-imports and re-exports. Net trade is calculated as the difference between imports and exports. In reality, actual physical flows may be larger in both directions between two countries, for example Austria and Germany (wood pellets), the Netherlands and Belgium (bioethanol and biodiesel), USA and Canada (biodiesel). In Figures of global trade streams, the EU is the leader in import of most of the studied products. For wood pellets, biodiesel and bioethanol, the additional figures show the trade streams within the EU and exclude trade streams outside of the EU. However, trade streams within the EU are sometimes related to imports from outside the EU. For example, the Netherlands imports biofuels from oversees and then re-exports to other EU countries. A report of the port of Rotterdam, which is the main port for ethanol trades, suggests a throughput of 3.8 Mt of biofuels including $1 \mathrm{Mt}$ of ethanol in 2014. ${ }^{18}$

For more reliable and comprehensive data, the study uses different sources for different products (Table 1). Where the sources give inconsistent data, volumes of studied products were calculated as averages. As each feedstock varies as regards data quality, data availability, amount used for energy end-use or other purposes etc., the methodological approach requires slight adjustment for each biomass type.

Table 1: List of data sources used for the products studied.

\begin{tabular}{|c|c|}
\hline Studied product & Main data sources \\
\hline Wood pellets & $\begin{array}{l}\text { "Global wood pellet industry - market and trade study } 2017 \text { " by IEA } \\
\text { Task } 4015^{19} \text {; Trade Map }{ }^{17} \text {; FAOSTAT statistics }{ }^{16} \text {. }\end{array}$ \\
\hline Bioethanol & $\begin{array}{l}\text { OECD-FAO agricultural outlook 2015-2024, FAOSTAT }{ }^{20} \text {; Trade } \\
\text { Map }^{17} \text {, USDA reports }\end{array}$ \\
\hline Biodiesel & $\begin{array}{l}\text { OECD-FAO agricultural outlook 2015-2024, } \text { FAOSTAT }^{20} \text {; Trade } \\
\text { Map }^{17} \text {, USDA report }{ }^{21} ; \text { AgMRC }^{26} ; \text { USDA }^{27} \text {. }\end{array}$ \\
\hline Palm oil & $\begin{array}{l}\text { Trade } \mathrm{Map}^{17} \text {; indexmundi }{ }^{28} \text {; Transport and Environment }{ }^{29} \text {; WWF }{ }^{30} \text {, } \\
\text { Oil World }{ }^{31} \text {. }\end{array}$ \\
\hline Charcoal & FAOSTAT $^{16} ;$ TradeMap $^{17} ;$ personal communication with experts. \\
\hline Industrial roundwood & FAOSTAT $^{16}$ \\
\hline
\end{tabular}

For wood pellets, data are taken from "Global wood pellet industry - market and trade study 2017" by IEA Bioenergy Task 40, ${ }^{19}$ which presents data collected by experts from different countries mostly based on local database sources. Data from this study are compared with FAOSTAT statistics ${ }^{16}$ and data from Trade Map (product code 440131) ${ }^{17}$.

For ethanol, trade streams are derived from Trade Map ${ }^{17}$ based on product code 2207 "Undenatured ethyl alcohol of an alcoholic strength of $>=80 \%$; ethyl alcohol and other spirits, denatured, of any strength". Product code 2207 does not include spirits, liqueurs and other spirituous beverages for human consumption, which are classified as product code 2208 . Export of ethanol from the USA is estimated based on UN Comtrade statistics compiled by UNSD (Quantity and Weight Data in UN Comtrade). 
Ethanol trade statistics do not differentiate between imported ethanol used for biofuels and for other purposes. Therefore, to improve the reliability of the international ethanol trade flow analysis, the study attempted to determine the share of ethanol that is used for energy in the importing country. By doing so, it is possible to quantify the share of the total traded volumes that is used for energy. The values presented should however be seen as an estimation due to the differences in trade flows and consumption reported by different available sources. From FAOSTAT statistics, ${ }^{20}$ the consumption of ethanol for biofuels use is taken as the difference between "total consumption" (for fuel) minus estimates for "for other uses". For Brazilian ethanol, ${ }^{21}$ the initial stocks for ethanol consumption for "all uses" are based on information from the Ministry of Agriculture, Livestock and Supply (MAPA); this information was consistent with previous ATO/Sao Paulo GAIN reports. Initial stocks for ethanol "for fuel only" are estimated based on historical average use of bioethanol for fuel/other uses. The total ethanol consumption was calculated based on the difference between total supply and demand (consumption and exports). A USDA report about ethanol in the $\mathrm{EU}^{22}$ presents volumes of ethanol used for fuel and other industrial chemicals excluding 'synthetic' ethanol made from petroleum fuels, which has a very small market in the EU. USDA data were compiled based on European Commission, Eurostat, Global Trade Atlas, ePURE and EU FAS posts. Data are compared also with other sources (for bioethanol ${ }^{23,24,25}$ and biodiesel ${ }^{26,27}$ )

For palm oil, trade streams data, which are taken from Trade Map, ${ }^{17}$ include both crude and refined palm oil and its derivatives, but exclude chemically modified palm oil products (code 1511). Production, consumption and trade streams are also cross-checked with IndexMundi. ${ }^{28}$ The use of palm oil for energy applications (transport fuel, electricity and heat) for the EU-28 is based on data from Transport and Environment, ${ }^{29}$ which in turn uses data from a publication of Oil World, ${ }^{31}$ and their estimates on usage by different industries. For earlier data, Transport and Environment ${ }^{29}$ used data from Fediol, which is the industry association representing the vegetable oil and protein meal industry in Europe. In most cases, national imports are first considered and then linked to an evaluation of where the oil is consumed by national industries. The national consumption of all member states is then summed. As such, the consumption of palm oil is presented by industry rather than end users. Palm oil consumption is thus presented as estimation.

To our knowledge, this study is a first attempt to map and quantify trade streams for charcoal. Charcoal trade streams include shell or nut charcoal, whether or not agglomerated, and exclude wood charcoal used as a medicament, charcoal mixed with incense, activated charcoal, and charcoal in the form of crayons (product code 440200). ${ }^{17}$ It is difficult to judge to what extent this data is complete. For example, informal charcoal trade between African countries may not be recorded in general global statistics due to a lack of documented data about such trade flows. Furthermore, such trade often occurs illegally, and it is thus hard to obtain accurate data or even estimates.

Trade flow data for industrial roundwood were taken from FAOSTAT, ${ }^{16}$ where industrial roundwood is defined as saw logs, pulpwood and other roundwood. Industrial roundwood data in this work refer to indirect trade in energy biomass, that is, the fraction of a biomass traded primarily for material purposes (e.g. roundwood to be processed into sawn wood in the destination country) that ultimately ends up in energy through usage of process residues (e.g. sawdust). ${ }^{3,4}$ The primary use of roundwood is for material applications, e.g. building 
construction, rather than for bioenergy. After product manufacture, some by-products such as residues and woody wastes are used as fuel for energy. Approximately 30-45\% of byproducts from roundwood usage can end up being used for energy purposes. Estimation of roundwood residue usage for energy purposes is rather complex and more detailed discussion of this topic is found in another paper in this issue, "Global biomass trade for energy: Part 1Statistical and methodological considerations". ${ }^{15}$

\section{RESULTS}

\subsection{Wood pellets}

The wood pellet market is one of the most dynamically developing solid biofuel markets in the energy sector. ${ }^{32-35}$ The leading wood pellet producers (Table 2) are USA, Canada and the EU-28, which produced over 14 Mt of wood pellets in 2015. The consumption of wood pellets was about $20 \mathrm{Mt}$ in the EU. ${ }^{19}$

Table 2: Global wood pellet production between 2010-2015 (in ktons). ${ }^{16,17,19}$

\begin{tabular}{|lrrrrrr|}
\hline Country/years & $\mathbf{2 0 1 0}$ & $\mathbf{2 0 1 1}$ & $\mathbf{2 0 1 2}$ & $\mathbf{2 0 1 3}$ & $\mathbf{2 0 1 4}$ & $\mathbf{2 0 1 5}$ \\
\hline USA & 3000 & 4000 & 4500 & 4900 & 6900 & 7500 \\
\hline Germany & 1700 & 1800 & 2200 & 2350 & 2080 & 2000 \\
\hline Canada & 1300 & 1400 & 1500 & 1750 & 1900 & 1900 \\
\hline Sweden & 1700 & 1400 & 1400 & 1300 & 1500 & 1600 \\
\hline Latvia & 615 & 725 & 1050 & 1105 & 1380 & 1380 \\
\hline Russia & 750 & 850 & 880 & 810 & 890 & 1050 \\
\hline France & 450 & 520 & 680 & 900 & 1030 & 1030 \\
\hline Austria & 820 & 920 & 850 & 950 & 945 & 1000 \\
\hline Estonia & 425 & 365 & 500 & 580 & 995 & 890 \\
\hline Poland & 430 & 600 & 600 & 600 & 620 & 870 \\
\hline $\begin{array}{l}\text { Rest of the } \\
\text { World }\end{array}$ & 3010 & 4420 & 6140 & 7755 & 8610 & 8780 \\
\hline World Total & 14200 & 17000 & 34300 & 23000 & 26850 & 28000 \\
\hline
\end{tabular}

In 2015, according to the statistics the total world import and export of wood pellets was 15.6 Mt and 16.0 Mt respectively. The difference in caused by statistical error (the volume recorded by exporting countries vs. the volumes recorded by the importing countries). In an ideal situation, world imports are equal to world exports. However, values may differ due to a numerous reasons for these discrepancies. For example, some trade deals could have been cancelled and because of categorization difference. Time lags can occur when, for example, exports are registered in one year and the corresponding import in the following year. ${ }^{15}$

In the USA, export of wood pellets increased from $1.9 \mathrm{Mt}$ (2012) to $4 \mathrm{Mt}$ (2014). ${ }^{16}$ In 2015 , the biggest wood pellet export destinations of the US were UK, Belgium and Italy. ${ }^{36}$ Recently, industrial wood pellet use has increased in South Korea and Japan (Figure 1), mainly to substitute coal in coal power plants. ${ }^{37}$ South Korea increased imports of wood pellets from 0.12 million tons in 2012 to 1.85 million tons in $2014,{ }^{38}$ and in 2016 became globally the third largest importer of wood pellets after Denmark and UK. ${ }^{39}$ In EU-28, total wood pellets imports were 13.4 Mt (Figure 2). The biggest importers of wood pellets in the EU in 2015 were UK (6.5 Mt), Denmark (2 Mt) and Italy $(1.6 \mathrm{Mt}) .{ }^{17,19}$ Italy uses wood pellets mostly for 
residential heating, whereas in the UK and Denmark, wood pellets are used almost exclusively for large-scale industrial operations, i.e., electricity and heat production.

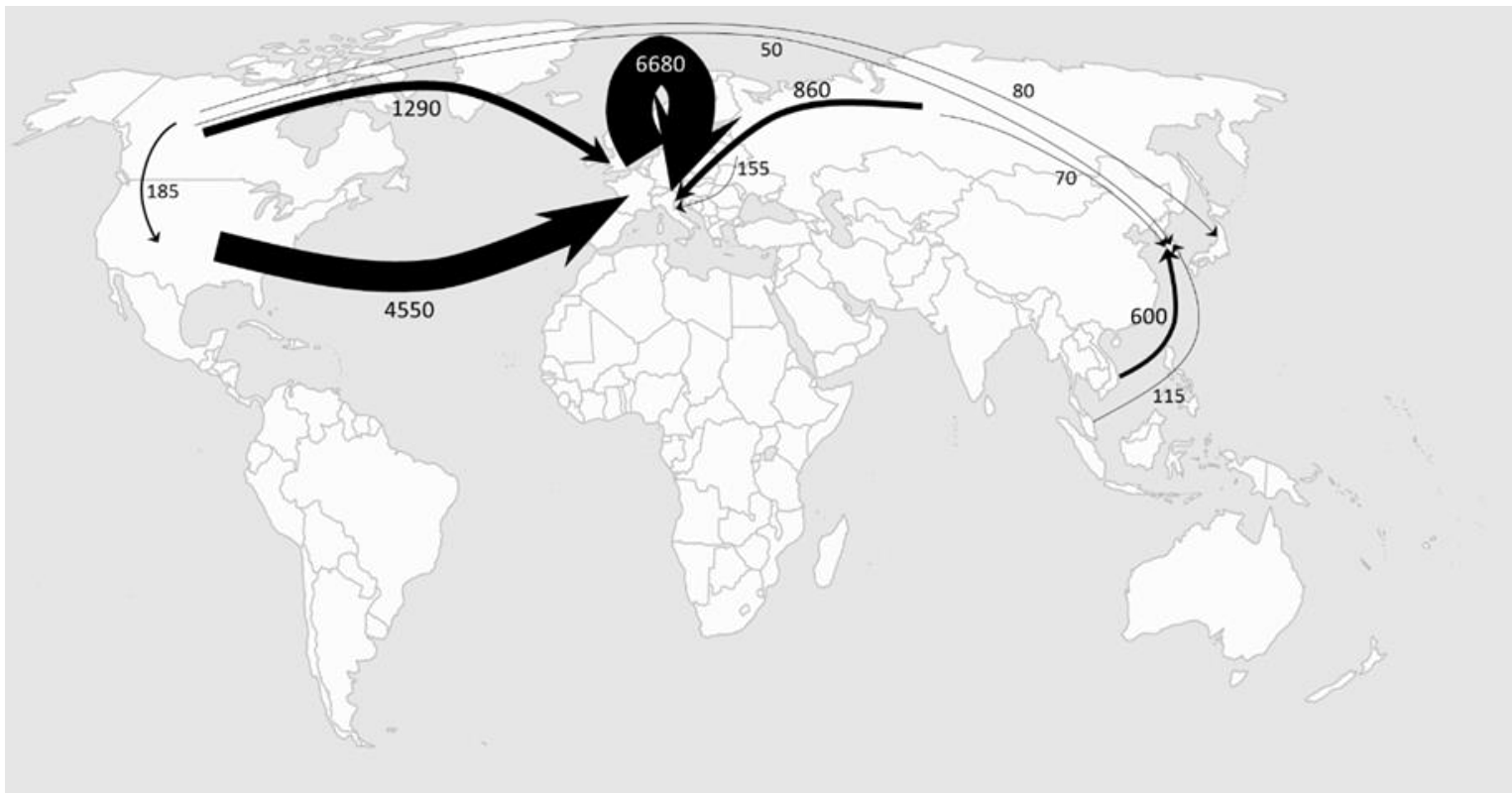

Figure 1. Major net wood pellets streams ( $\geq 30$ ktons), (in ktons) in 2015. Data were obtained from $^{16,17,19}$

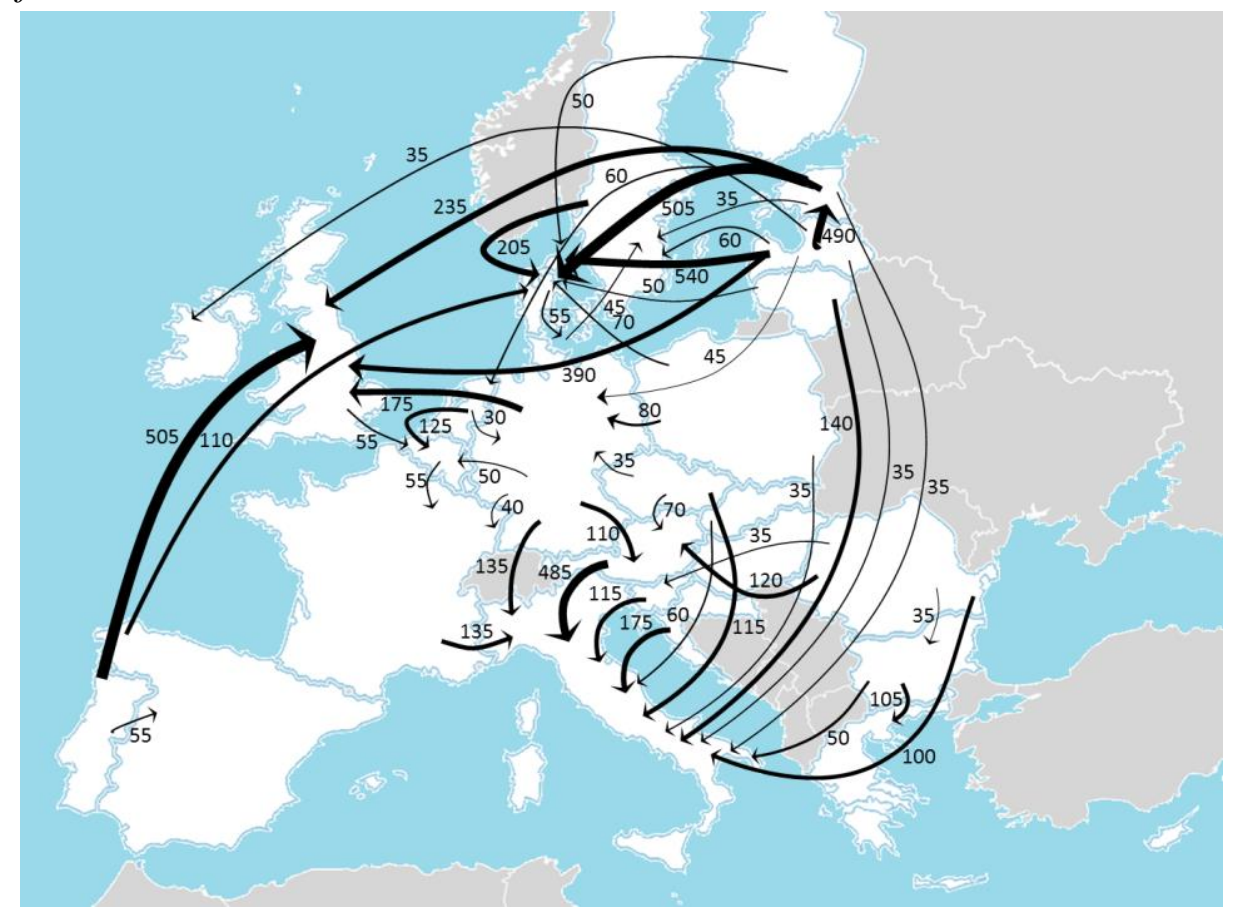

Figure 2. Net wood pellets trade streams within the EU-28 ( $\geq 30 \mathrm{ktons})$, (in ktons) in 2015.

Data were obtained from ${ }^{16,17,19}$. For imports from outside the EU (US, Canada, Russia), see Figure 1.

In 2015, the Baltic countries Estonia, Latvia and Lithuania accounted for 35\% of all European wood pellet exports with a total pellet production of $2.7 \mathrm{Mt}$ and total exports of $2.8 \mathrm{Mt},{ }^{19}$ which can explained changes in storages and slight import of wood pellets to the Baltic countries. Baltic countries have great potential for future wood pellet industry development because they have abundant forests, low costs and close proximity to naval ports. ${ }^{36}$ Portugal also has potential for further development of wood pellets exports due to abundant forest 
resources, relatively low production costs (e.g. 30\% less than in Germany) and limited local consumption. ${ }^{19}$ In recent years, however, wood pellet market development has been relatively slow, and oversupply occurred in European markets between 2012 and 2015, mainly due to a series of mild winters. In addition, global oil prices have decreased, causing demand for residential wood pellets to slow. ${ }^{40}$

\subsection{Liquid biofuels}

The USA and Brazil are leaders in the ethanol market with $75 \%$ of the world's ethanol production (Table 3). 97\% of ethanol produced in the USA is derived from corn, and $38 \%$ of all corn production in the country is utilised for ethanol production. ${ }^{41}$ In 2015 , the primary exporters of ethanol were the USA $(1.7 \mathrm{Mt})$ and Brazil $(1.5 \mathrm{Mt})$ (Figure 3$).{ }^{17}$ Ethanol has become an important commodity for USA markets thanks to strong policy support. ${ }^{23}$ The industry has matured in terms of corn processing, which suggests that USA will remain the leading player in ethanol markets for many years to come. ${ }^{42}$ Following the increase in local ethanol production, USA imports have fallen dramatically. ${ }^{24}$ When considering intra-EU trade, the Netherlands is the biggest recipient of ethanol exports in the EU-28 (Figure 4).

Table 3: Global ethanol production between 2006-2015 (in ktons). Data were obtained from 20,22,23,24. Density of $785.06 \mathrm{~kg} / \mathrm{m}^{3}$ is assumed.

\begin{tabular}{|llllllll|}
\hline Country/Years & $\mathbf{2 0 0 6}$ & $\mathbf{2 0 1 0}$ & $\mathbf{2 0 1 1}$ & $\mathbf{2 0 1 2}$ & $\mathbf{2 0 1 3}$ & $\mathbf{2 0 1 4}$ & $\mathbf{2 0 1 5}$ \\
\hline USA & 15070 & 41090 & 43035 & 40850 & 41320 & 44920 & 44585 \\
\hline Brazil & 14070 & 21645 & 17850 & 18450 & 21955 & 22160 & 23660 \\
\hline China & 4935 & 6500 & 6740 & 7005 & 6090 & 5895 & 6010 \\
\hline EU-28 & 2700 & 4940 & 5215 & 5205 & 5500 & 5535 & 5900 \\
\hline India & 1220 & 1265 & 1570 & 1515 & 1600 & 1785 & 1780 \\
\hline $\begin{array}{l}\text { Rest of the } \\
\text { World }\end{array}$ & 4280 & 6195 & 6725 & 7690 & 8325 & 9030 & 9565 \\
\hline World Total & 42275 & 81635 & 81135 & 80715 & 84790 & 89325 & 91500 \\
\hline
\end{tabular}

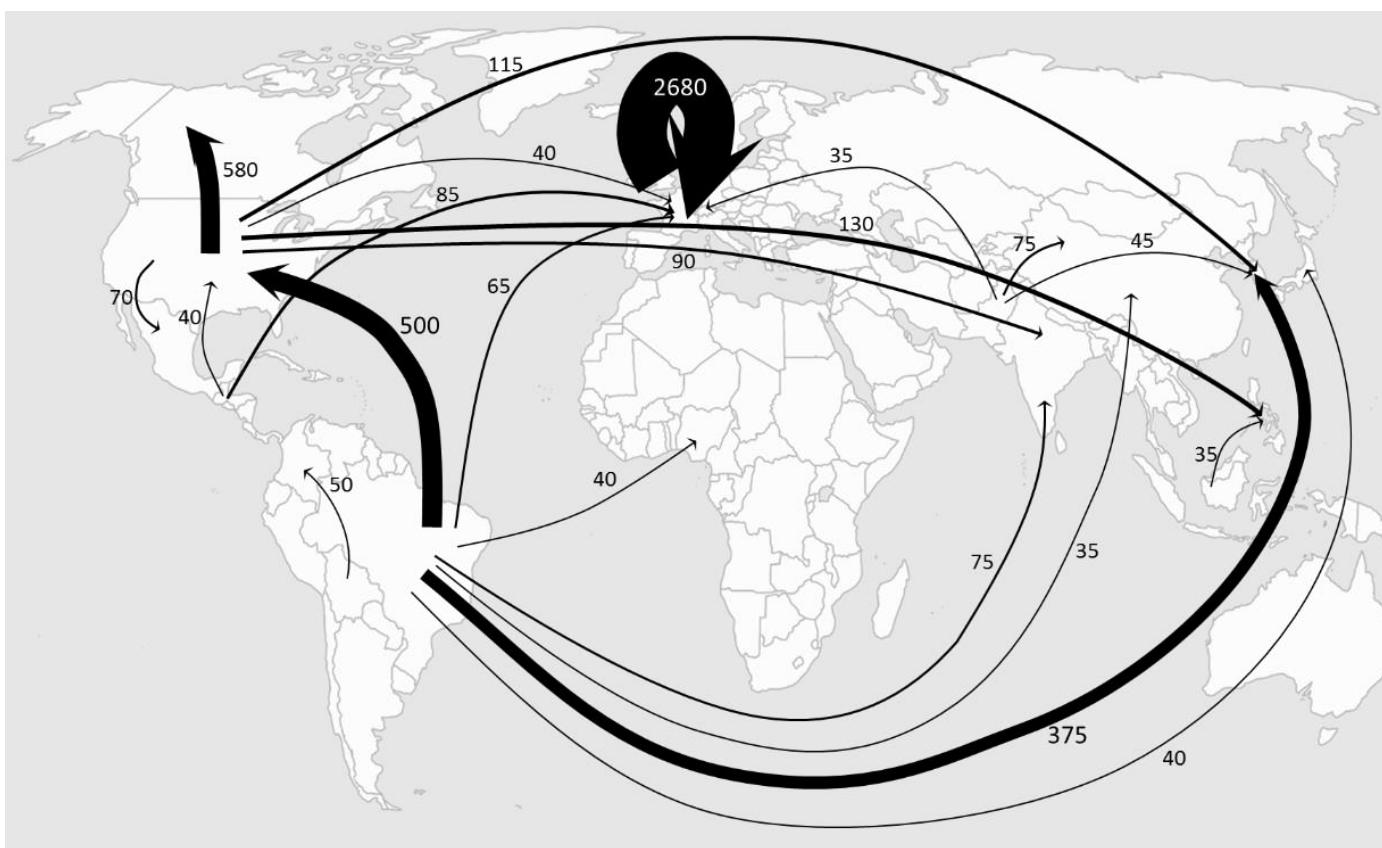

Figure 3. Major net ethanol trade streams ( $\geq 35 \mathrm{ktons})$ used for all end-uses, (in ktons) in 2015. Data were obtained from ${ }^{12,17,21,22,25}$. 


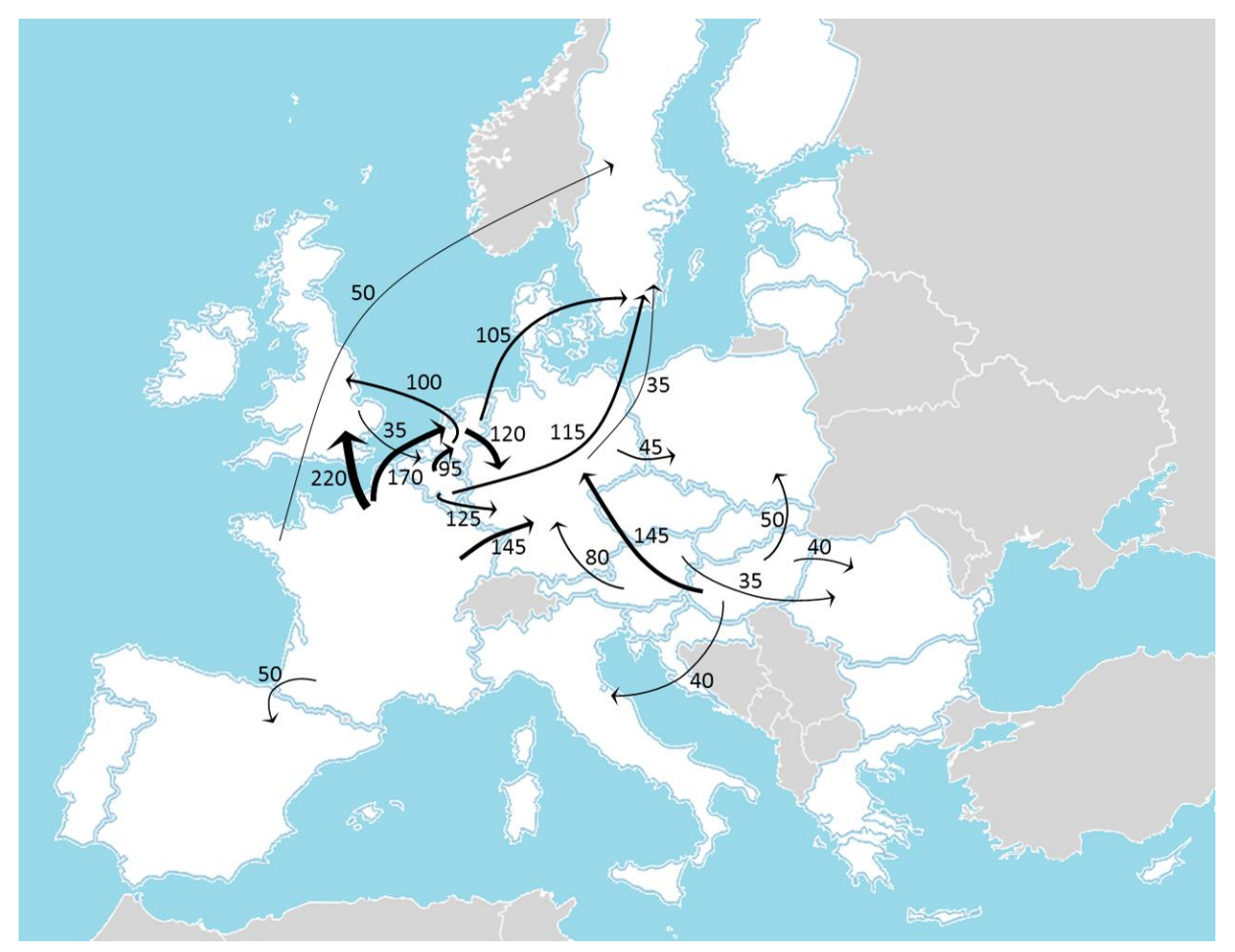

Figure 4. Net ethanol trade streams within the EU-28 ( $\geq 30$ ktons), (in ktons) 2015. Data were obtained from ${ }^{17,21}$. For imports from outside the EU (US, Brazil, Guatemala and Pakistan), see Figure 3.

The USA, the Caribbean countries and Sweden mainly import ethanol from Brazil for fuel usage, whereas Japan, South Korea and several other importing countries, including countries in the EU, import Brazilian ethanol for industrial and other uses. ${ }^{21}$ Overall, more than $90 \%$ of the global ethanol consumption is used as biofuel. Figure 5 presents an estimation of how much of total ethanol consumption is for transport fuel use, based on combining different statistics for main ethanol consumers. For ethanol use as fuel in the USA, the data from EIA ${ }^{25}$ differs slightly from that published by FAOSTAT $^{20}$ (e.g. 41.45 ktons instead 42.16 ktons in 2015). Also for Brazil, FAOSTAT ${ }^{20}$ and USDA $^{21}$ reported slightly different volumes for ethanol consumption and its use as biofuel for 2011-2015. Overall, it is clear that ethanol consumption for technical and other purposes has remained relatively stable and increase in consumption is mainly due to use as transport fuel. 


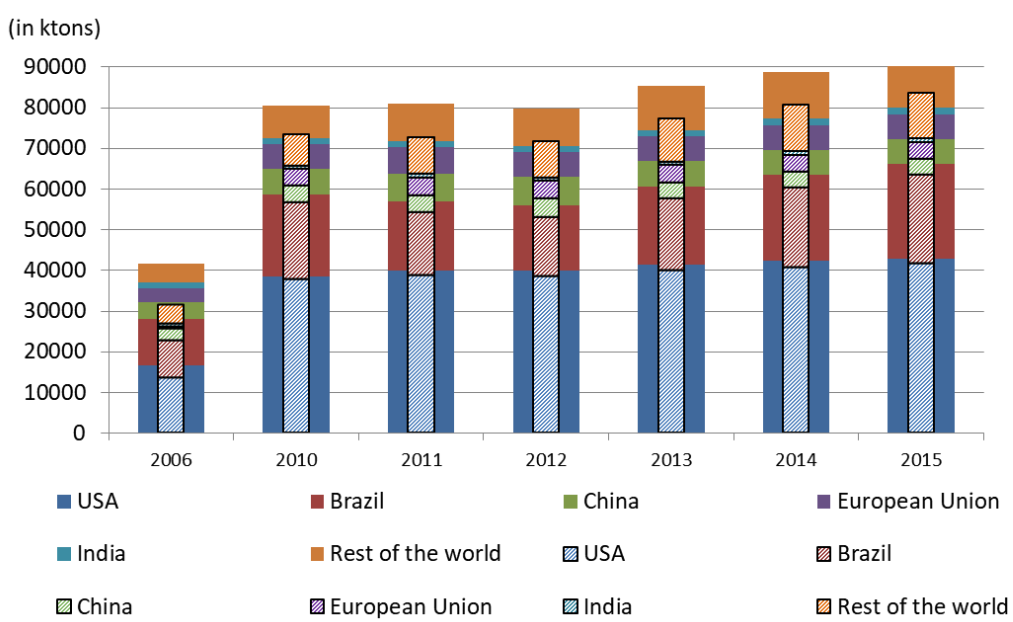

Figure 5. Consumption of ethanol for biofuels use (narrow bars) and total ethanol consumption (wide bars) (in ktons) ${ }^{20}$ for Brazil ${ }^{20,21}$, for the EU-28 $8^{20,22}$, for USA. ${ }^{20,25}$ Density of $785.06 \mathrm{~kg} / \mathrm{m}^{3}$ is assumed.

Like bioethanol production, global biodiesel production has increased significantly over the last ten years (Table 4) ${ }^{20}$ In the USA, a peak of biodiesel production occurred in 2013 due to increased consumption, which can be explained by factors such as the need to satisfy total renewable fuel standards, biodiesel tax credits, growing access to foreign biodiesel, mostly from Argentina, and favourable blending economics. ${ }^{26}$ In the EU-28, production of biodiesel is mainly based on imports. In 2015, the EU imported about 53\% of feedstocks (vegetable oils mainly from rapeseed, palm and soya) used to produce crop biodiesel in EU installations. ${ }^{43}$ The EU-28 consumed about $12.9 \mathrm{Mt}$ of biodiesel in $2015 .^{22}$

Table 4: Global biodiesel production for 2006-2015 (in ktons). Data were obtained from ${ }^{20,22,26}$. Density of $885.00 \mathrm{~kg} / \mathrm{m}^{3}$ is assumed.

\begin{tabular}{|llllllll|}
\hline Country/Years & $\mathbf{2 0 0 6}$ & $\mathbf{2 0 1 0}$ & $\mathbf{2 0 1 1}$ & $\mathbf{2 0 1 2}$ & $\mathbf{2 0 1 3}$ & $\mathbf{2 0 1 4}$ & $\mathbf{2 0 1 5}$ \\
\hline EU-28 & 4870 & 9580 & 9120 & 9725 & 10380 & 10645 & 12000 \\
\hline USA & 840 & 1150 & 3250 & 3390 & 5150 & 5130 & 4005 \\
\hline Brazil & 60 & 2110 & 2365 & 2405 & 2580 & 3290 & 3990 \\
\hline Indonesia & 55 & 655 & 1345 & 1595 & 1800 & 2035 & 3020 \\
\hline Argentina & 0 & 2415 & 2440 & 2470 & 2010 & 2335 & 2350 \\
\hline $\begin{array}{l}\text { Rest of the } \\
\text { World }\end{array}$ & 485 & 1860 & 2230 & 2715 & 2895 & 3325 & 3135 \\
\hline World Total & 6310 & 17770 & 20750 & 22300 & 24815 & 26760 & 28500 \\
\hline
\end{tabular}

The US was a net exporter of biodiesel from 2007 to 2012 and then became a net importer from 2013 to $2015 .^{26}$ Export of biodiesel from many non-European countries to the EU is relatively small (Figure 6) due to EU anti-dumping policy. ${ }^{44}$ Extra-EU imports of biodiesel decreased from about 2.8 Mt (2012) to about $0.8 \mathrm{Mt}$ (2014). ${ }^{45}$ Nevertheless, in 2015, the main importers of biodiesel from Malaysia were Spain, Switzerland and the Netherlands with 65\%, $19 \%$ and $11 \%$ of total exports from Malaysia respectively. Spain and the Netherlands reexported the largest part to other EU member states (Figure 7). Malaysia increased exports of biodiesel from about 330 ktons in 2014 to 615 ktons in 2015 . $^{27}$ 


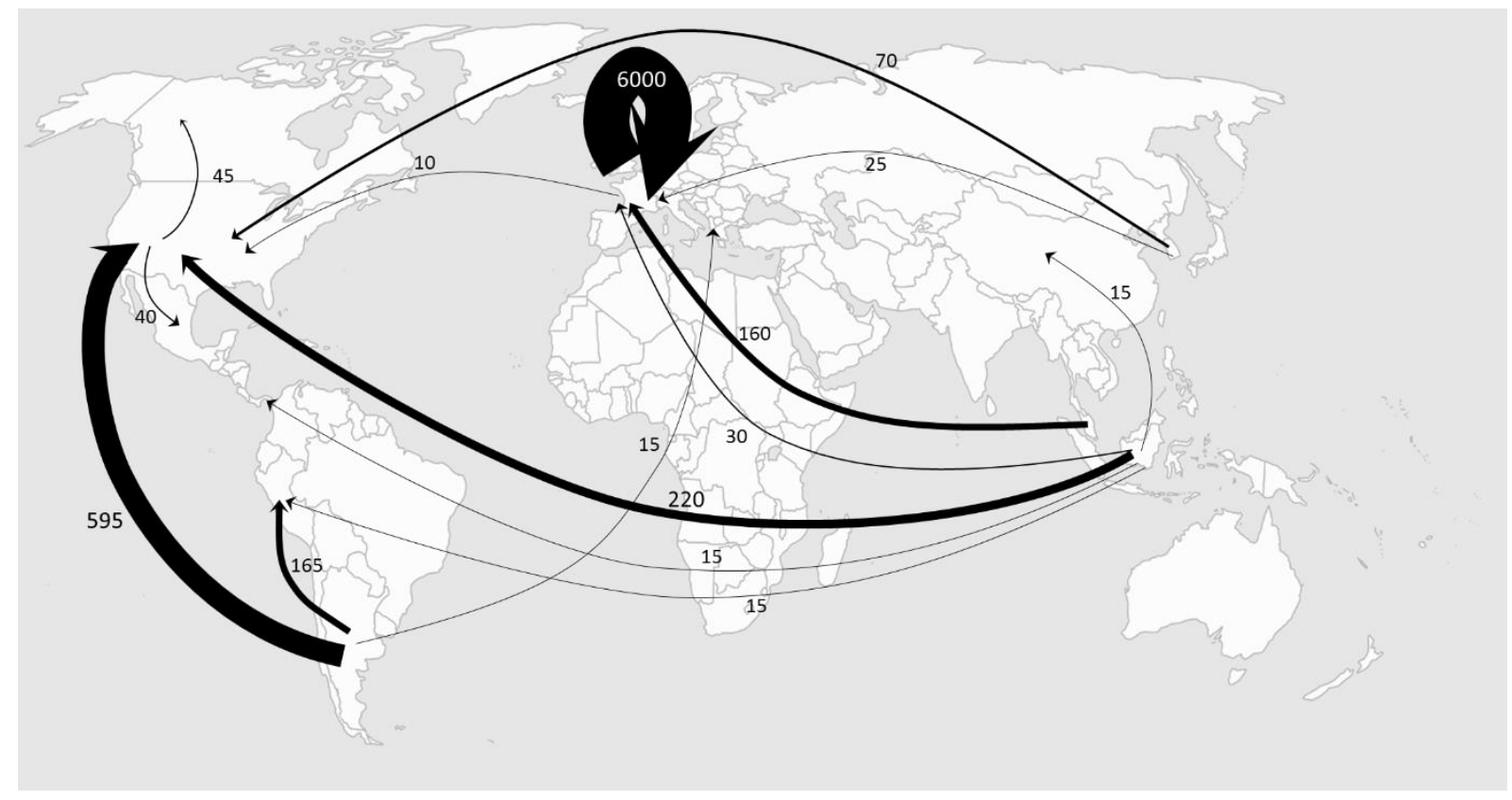

Figure 6. Major net biodiesel trade streams ( $\geq 10 \mathrm{ktons})$, (in ktons) in 2015. Data were obtained from ${ }^{17,26,27}$.

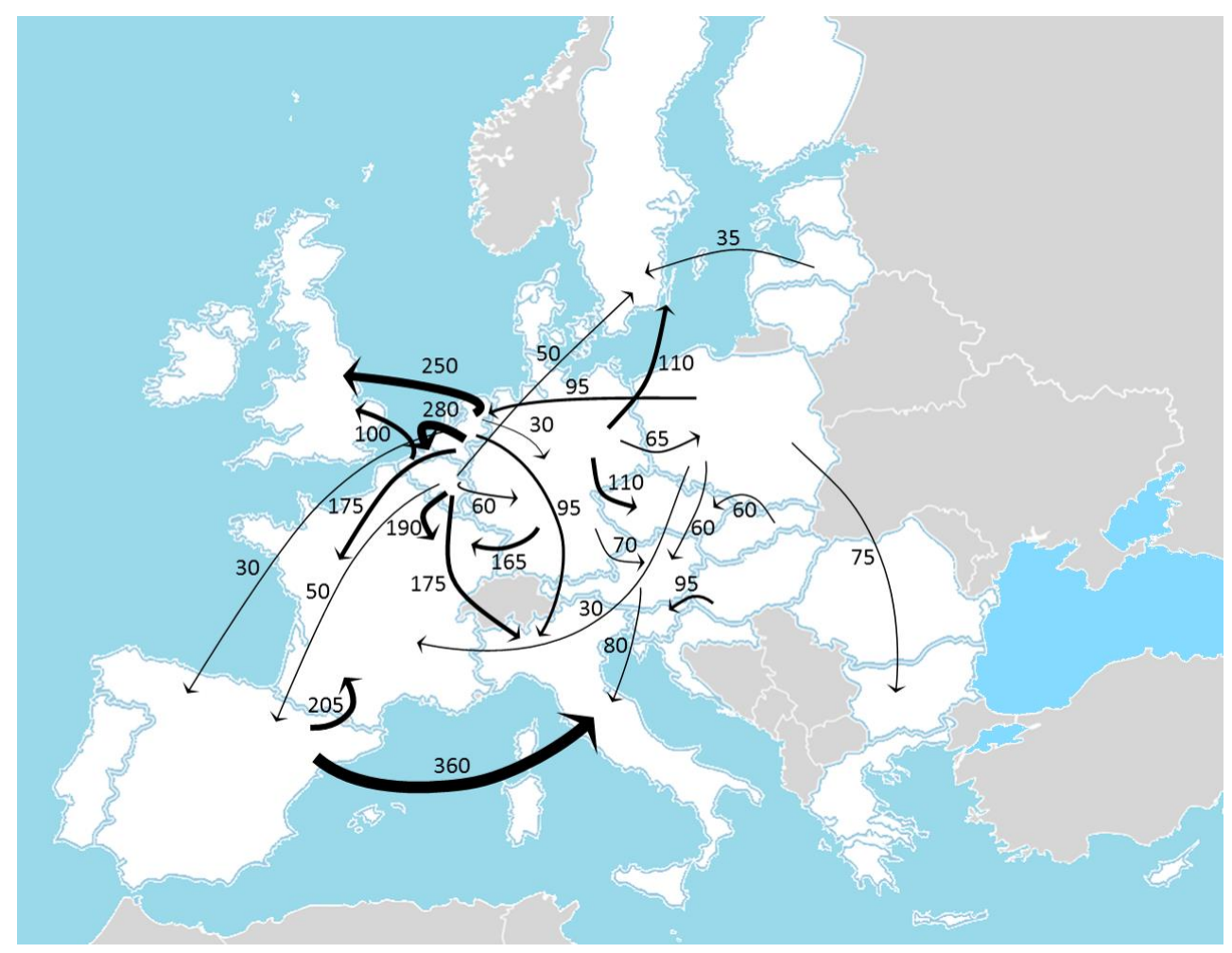

Figure 7. Net biodiesel trade steams within the EU-28 ( $\geq 30 \mathrm{ktons}$ ), (in ktons) 2015. Data were obtained from $^{17,22}$. For imports from outside the EU (Malaysia and Indonesia), see Figure 6.

Palm oil can be used for biofuel production using a wide range of different technical approaches. $^{46}$ In 2015, the main global producers of palm oil were Indonesia (33.4 Mt), Malaysia $(29.9 \mathrm{Mt})$ and Thailand $(1.8 \mathrm{Mt}){ }^{47}$ The main importers of palm oil were India, the EU-28 and China (Figure 8). ${ }^{17}$ In India, imports of palm oil have risen strongly over the last decade. In 2014, India imported about $8.8 \mathrm{Mt}$ of palm oil, while domestic production was about 0.05 Mt. Approximately $90 \%$ of imported palm oil is used for edible products (mostly 
as cooking oil), and the remaining $10 \%$ goes toward non-food-based usage such as cosmetics and detergents. ${ }^{48}$ The share of palm oil used in India for biodiesel is negligible. China also uses palm oil mainly for food $(70 \%)$, with the remaining oil mostly being used in the chemical industry. ${ }^{30}$

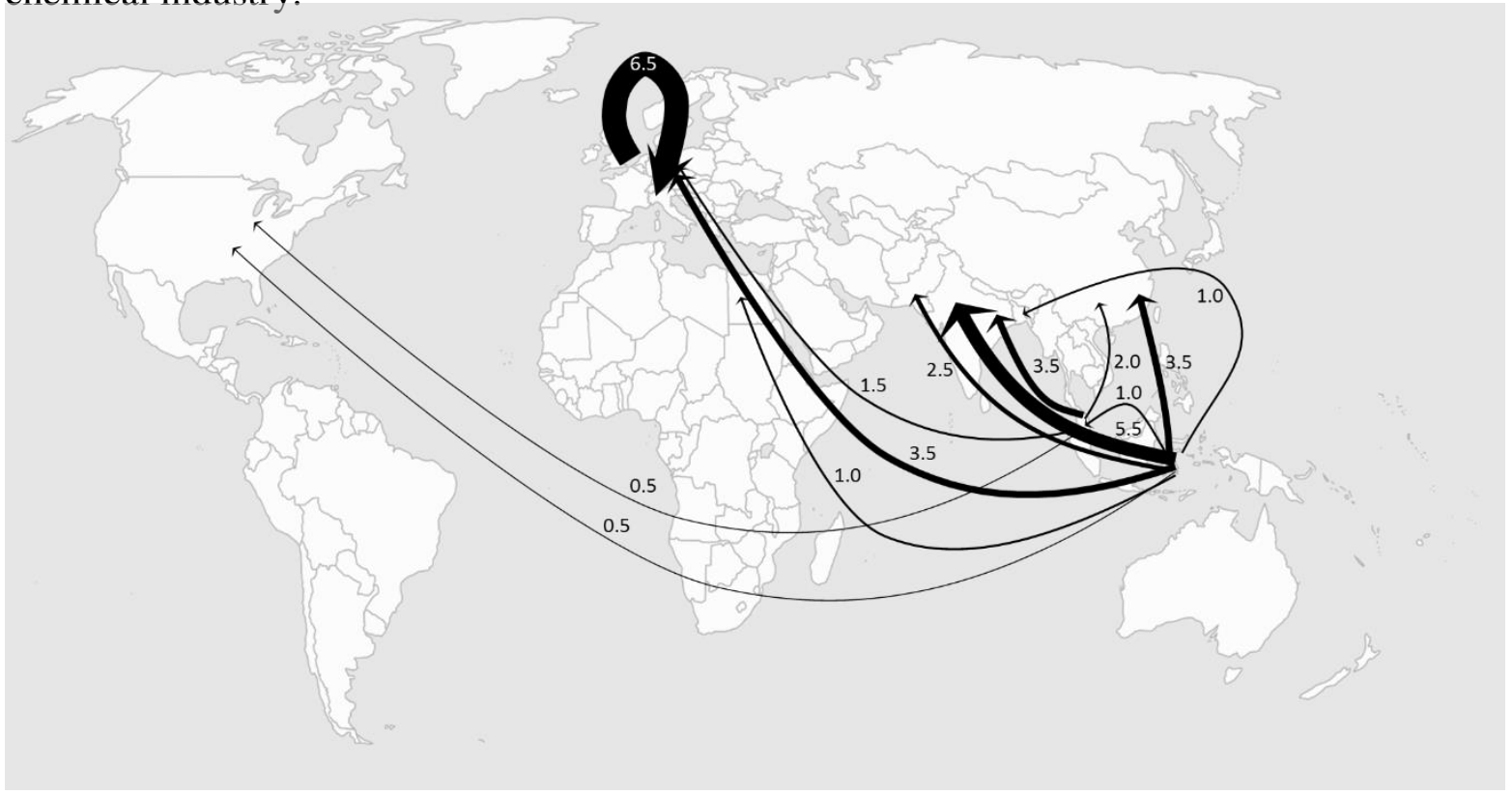

Figure 8. Major palm oil streams ( $\geq 500$ ktons), (in Mtons) in 2015. Data were obtained from $^{17,28,31}$.

In the EU-28, after rapeseed oil, the most dominant feedstock for biodiesel production is palm oil. Imported palm oil used for the production of biodiesel increased between 2010-2014 (Figure 9). ${ }^{29,43}$ In the EU-28, the leaders in palm oil consumption are the Netherlands, Germany and Italy. In 2015, the Netherlands imported about 130 ktons of palm oil for biodiesel production, of which $85.4 \%$ and $14.6 \%$ were from Malaysia and Indonesia respectively. ${ }^{49}$ Germany used 128 ktons of palm oil for biodiesel production (Fatty Acid Methyl Esters, FAME) and 164 ktons for renewable diesel fuel (Hydrotreated Vegetable Oil HVO) in $2015 .^{50}$

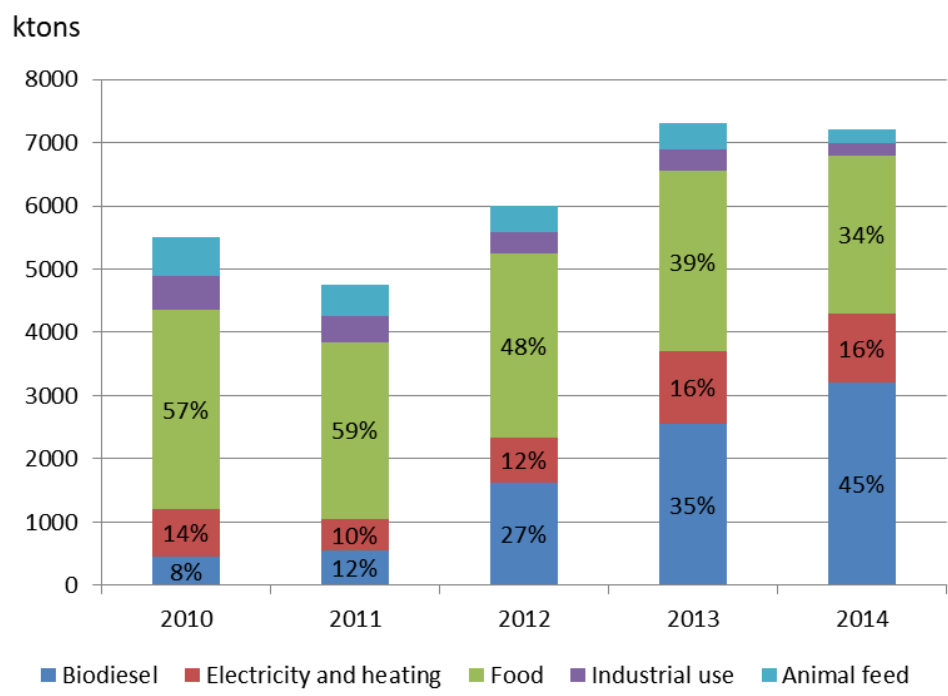

Figure 9. Palm oil consumption in the EU. Data were obtained from ${ }^{29,43}$. 


\subsection{Charcoal}

In 2015, formally recorded world production of charcoal was around $52 \mathrm{Mt}$ and documented export of charcoal slightly more than $2 \mathrm{Mt} .{ }^{16}$ The charcoal trade doubled between 2008 and 2015, which can be partly explained by increasing charcoal use for cooking in Africa, the Middle East and Asia. Figure 10 presents preliminary estimates of major charcoal trade streams.

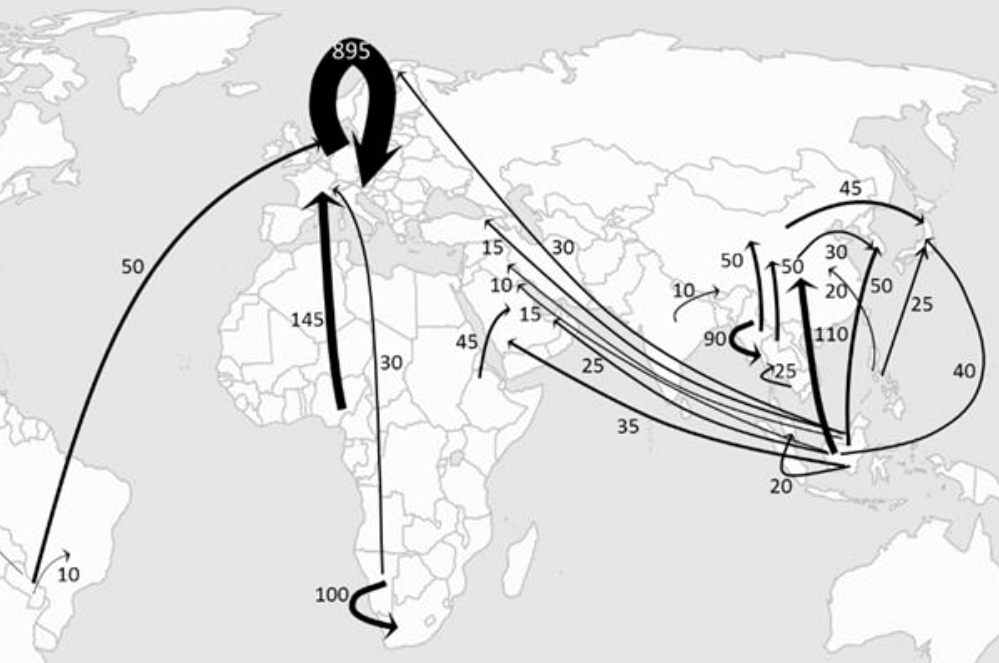

Figure 10. Major charcoal trade streams ( $\geq 5$ ktons), (in ktons) in 2015. Data were obtained from ${ }^{16,17}$.

\subsection{Industrial roundwood}

The leading industrial roundwood produsers are USA, the EU-28 and Russia (Table 5). The largest importers of industrial roundwood are China and the EU (Figure 11). In the EU, the main markets of industrial roundwood are located in Denmark, Finland, Sweden, Germany, Estonia, Latvia, Lithuania and Poland. The large amount of roundwood imported into China may be explained by the fact that China is a major exporter of wood-based panel products. In the past few years, the country has become the largest global importer of wood products due to growth in domestic consumption and export-oriented manufacturing activities. ${ }^{51}$

Table 5: Global roundwood production for 2006-2015 (in $\mathrm{Mm}^{3}$ ). Data were obtained from ${ }^{16}$.

\begin{tabular}{|lrrrrrrc|}
\hline Country/years & $\mathbf{2 0 0 6}$ & $\mathbf{2 0 1 0}$ & $\mathbf{2 0 1 1}$ & $\mathbf{2 0 1 2}$ & $\mathbf{2 0 1 3}$ & $\mathbf{2 0 1 4}$ & $\mathbf{2 0 1 5}$ \\
\hline USA & 410 & 335 & 355 & 350 & 355 & 355 & 370 \\
\hline Russia & 175 & 160 & 175 & 175 & 180 & 190 & 190 \\
\hline Canada & 180 & 140 & 145 & 145 & 150 & 150 & 150 \\
\hline China & 95 & 160 & 160 & 160 & 170 & 160 & 165 \\
\hline EU-28 & 340 & 340 & 340 & 330 & 335 & 345 & 350 \\
\hline $\begin{array}{l}\text { Rest of the } \\
\text { World }\end{array}$ & 535 & 570 & 595 & 605 & 610 & 620 & 650 \\
\hline World & 1735 & 1705 & 1770 & 1765 & 1800 & 1820 & 1875 \\
\hline
\end{tabular}




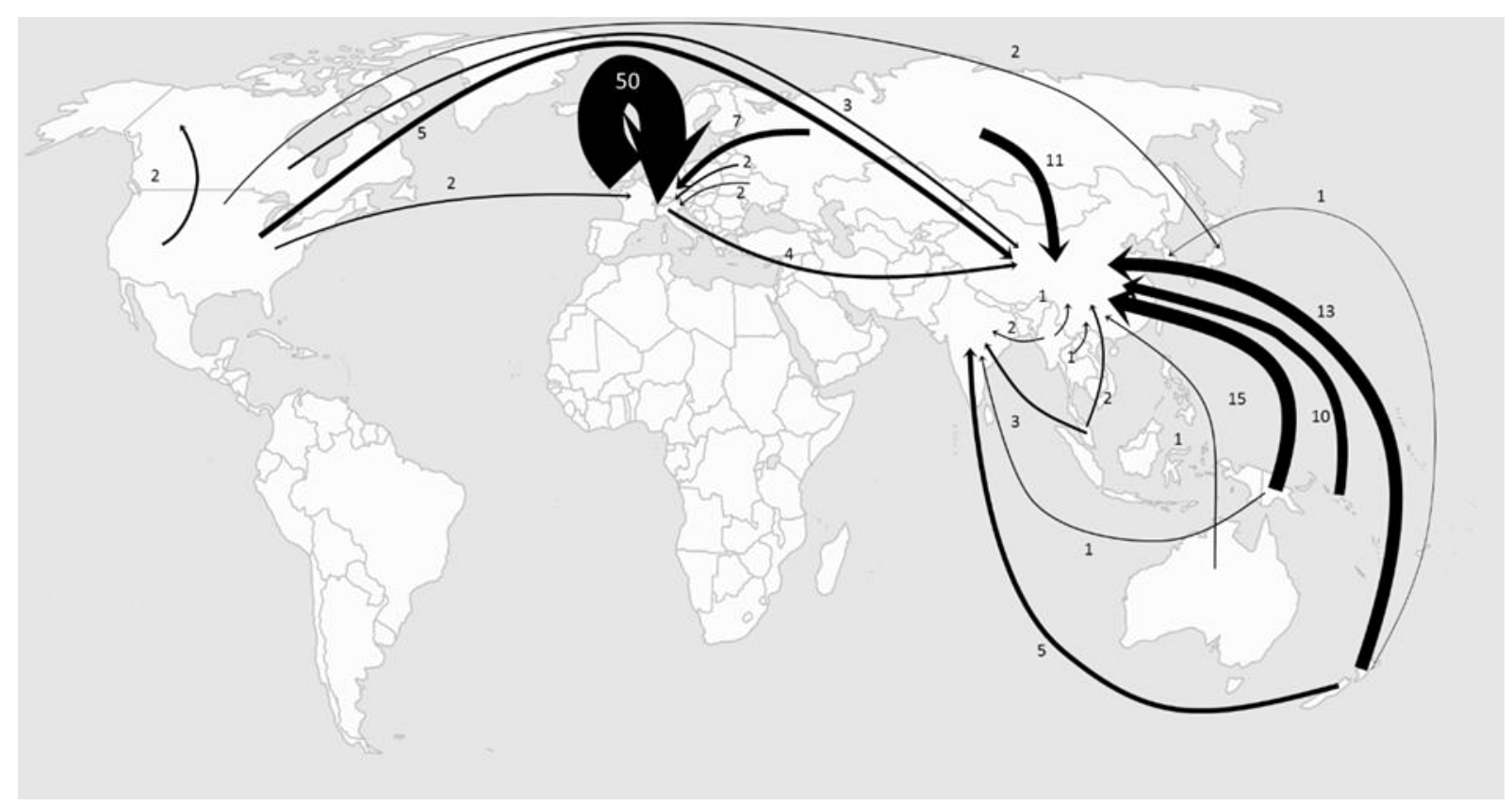

Figure 11. Main net global trade streams of industrial roundwood $\left(\geq 1 \mathrm{Mm}^{3}\right)$, (in $\left.\mathrm{Mm}^{3}\right)$ in 2014. Data were obtained from ${ }^{16}$.

\subsection{Review of emerging biomass for energy streams}

In the long term, new trade streams of biomass for energy can emerge. For example, torrefied biomass is very attractive as a biofuel product for long-distance transportation. Torrefied biomass has a greater density and heating value than raw wood, which makes transportation easier and more economic. ${ }^{52,53}$ According to IEA Task $40,{ }^{52}$ global torrefied biomass demand in industrial applications could theoretically reach more than $7 \mathrm{Mt}$ by 2025. Different scenarios indicate that total torrefied biomass demand might reach $10-18 \mathrm{Mt}$ by $2030 .{ }^{53}$ However, the market for torrefied biomass is not yet well-developed and global production capacity is currently far below $1 \mathrm{Mt}$ per year.

Another emerging commodity traded for energy is used cooking oil (UCO), which is uniquely used for biodiesel as a replacement for mineral diesel (in the form of used cooking oil methylester (UCOME) and hydro treated vegetable oil (HVO)) and for bio-kerosene. From the technical point of view, biodiesel production from UCO uses similar methods to conventional transesterification processes. ${ }^{54} \mathrm{UCO}$ is collected all over the world. In the last few years, traded volumes of UCO have increased. ${ }^{55}$ Due to double counting of biofuels produced from UCO under the Renewable Energy Directive (RED) and because the EU imports UCO from all over the world, evaluation of the level of trade for the EU-28 is difficult. In the EU, about $1 \mathrm{Mt}$ of UCO per year was used for biodiesel production in past years. ${ }^{49,55}$ UCO is collected in several EU countries such as Germany, the Netherland and Italy. For example, in the Netherlands, collection of UCO from restaurants is nearly $100 \%$. Approximately 60 ktons of UCO were collected in the Netherlands and even more was imported from other EU Member States and third countries. ${ }^{55}$ Use of UCO can decrease biodiesel production costs. If shortages of UCO in the EU occur, imports may increase, and the cost of obtaining the raw material may be higher. Generally, in EU countries, the biodiesel production chain from UCO has essential economic and environmental benefits. ${ }^{54}$ The traded volumes of charcoal are comparable with traded volumes of used cooking oil (UCO). 
However, the trade streams for UCO are not shown due to the limited information available (documentation of UCO trade is a new subject).

Aviation biofuel (biomass-derived jet fuel) could also become a new biomass commodity. At present, however, there is no large scale aviation biofuel production, and thus also no international trade. The European Advanced Biofuels Flightpath has set a target to ensure the commercialization and consumption of $2 \mathrm{Mt}$ of sustainably produced paraffinic biofuels in the aviation sector by 2020 (for more details see the study by Kousoulidou and Lonza ${ }^{56}$ ). Despite such efforts, in the coming years, the demand and production of aviation biofuel are expected to remain negligible compared to conventional fossil jet fuel. ${ }^{57}$

Last but not least, another example of a bio-product that in future years could be traded for energy purposes is biochar, which is a solid material obtained from thermochemical conversion of biomass in an oxygen-limited environment. In Europe, total consumption of biochar was 22.6 tons in 2015, while in 2011 it was about 12 tons. Europe uses biochar mostly for soil amendment as soil conditioner (47.5\%) and fertilizer (33.8\%). Energy applications account for about $18.7 \%$ of total biochar use. The use of biochar for energy has increased from 2.4 tons (2011) to 4.2 tons (2015). The price of biochar is high for energy applications. European imports of biochar were 2.2 tons in 2015, while in 20111.1 tons. $^{58}$

\section{DISCUSSION}

The current study found that wood pellet markets have significantly developed during last five years. The large trade in wood pellets can be explained by increased demand in the heating and industrial sectors. In both sectors, global wood pellet markets have increased significantly in the past decade. In the EU, the high wood pellet consumption and significant imports can be explained by historical reasons - use of wood pellets started in Sweden, renewable energy development trends and by policy support and environmental issues. Different scenarios suggest that European wood pellet markets will grow still further. ${ }^{19,59}$

It seems that Asian wood pellet markets will continue development thanks to policy support and the global trend of wood pellet market development. In South Korea, widespread interest in wood pellets started from a renewable portfolio standard that became effective in 2012 and had the goal of reaching $10 \%$ energy generation from renewable resources in the 2022 to 2027 timeframe. ${ }^{38}$ Also Japan is expected to increase wood pellet imports quite substantially over the next five years. ${ }^{57}$ The abundance of primary forest feedstock and by-products from forest products manufacture, as well as relatively low production costs, make Vietnam a very promising country for wood pellet market development. ${ }^{38}$ Malaysia, Indonesia and Thailand also have potential for further development. Indonesia almost doubled production and export during 2013-2014. Thailand increased wood pellet production from 20,000 tons in 2013 to 115,000 tons in $2015 .^{38}$

The relatively low levels of ethanol exports from the USA to Europe can be explained by an anti-dumping duty on bioethanol imports from the US imposed by the European Commission. At the beginning of 2013 , the duty was set at $€ 49.20$ per 1,000 litres ( 0.785 tons) for the following five years, on top of an existing import tariff of $€ 102$ per 1,000 litres. In the medium term, it is questionable whether corn-based ethanol will be exported to the EU, as the minimum greenhouse gas savings criteria is being increased to $50-60 \%$ from the current $35 \%$ threshold. $^{22}$ 
In Brazil, the stagnation of ethanol production between 2009 and 2014 had multiple causes. The economic crisis of 2008 delayed sugar cane replanting for $2009,{ }^{60}$ and combined with unfavourable weather conditions the crisis had a highly negative impact on ethanol production. ${ }^{12}$ Lastly, in 2009-2014, ethanol became less competitive due to the government's reduced support for ethanol production and the introduction of price freezes, which favoured fossil fuels. ${ }^{61}$ This unfavourable business environment led to the closure of some ethanol production facilities and fewer facilities being built. Brazil has a large potential of biomass resources and well placed to continue to be a dominant player in exporting resources for global trade in the future. ${ }^{62}$

Although palm oil is globally the most important vegetable oil used for human consumption, it is increasingly also being used for biodiesel production. Some sources believe that palm oil biodiesel, produced from refined palm oil, will become one of this century's most important commodities. ${ }^{63}$ However, the negative environmental impacts associated with palm oil production, the $7 \%$ cap on food-based biofuels and the increasing greenhouses gases threshold in the EU are plausible reason to believe that palm oil use as a fuel will actually decrease. In Indonesia and Malaysia palm oil exports bring considerable profits for the economies of these countries. However, processes of direct and indirect land-use change have caused deforestation and the conversion of carbon-rich peatlands into palm tree plantations. ${ }^{64}$ For these environmentally-related reasons, some European countries, such as the UK, are disinclined to use palm oil for biodiesel production or other energy production purposes.

For production of one ton of wood-based charcoal, 5-12 tons of wood are required. ${ }^{65}$ Due to poor post-harvest management, charcoal production, especially in countries such as Indonesia, Philippines and Nigeria, contributes to forest degradation. It should also be noted that there is much illegal charcoal trade in many African countries. ${ }^{66}$ The Nigerian National Council on the Environment has called for cessation of the production and export of charcoal from Nigeria. Thus far, this demand has however been ignored by local authorities. ${ }^{65}$ Exports of charcoal from countries such as Nigeria, but also Indonesia and Myanmar, should be questioned in terms of sustainability given the ongoing deforestation in these countries.

\section{CONCLUSION}

This study shows the main trade streams of industrial roundwood, wood pellets, ethanol and biodiesel, as well as considering trade in palm oil and charcoal, and more briefly some emerging bioenergy trade flows that have been identified. The research extends knowledge of international biomass trade streams, and the overview presented can be of value for creating scenarios of further development of biomass trade markets.

On the whole, all solid and liquid biofuels show a steady increase in production and reach a maximum in 2015 , the last year studied. The conclusion can be drawn that trade stream volumes have potential to continue their growth. Interestingly, use of palm oil for energy has increased in the EU despite concerns about related environmental issues. Perspectives for the palm oil trade for energy seem unclear due to sustainability issues, which have been the subject of considerable debate. In the long term, additional bioenergy trade flows, both as regards the products traded and the trading routes used, can be expected to emerge and establish their own niche in international biomass trade in biomass for energy.

Our findings show that the biomass trade for energy covers many different countries and many different products. In recent years, Asian markets have developed considerably, for 
example, Malaysia and Indonesia (palm oil), and Thailand, Vietnam, South Korea and Japan (wood pellets). Further increasing demand on Asian markets will play an increasingly important role in the global wood pellet trade, which can be expected to change current global trade streams. In Europe, the Baltic countries Estonia, Latvia and Lithuania have made much progress in the export of wood pellets. The EU is the main leader in biomass utilisation and the main importer of most biomass products. Divergent policy regulation and large price differentials have led to complex wood pellet trade streams within the EU.

Many different factors influence current biomass trade streams, such as historical bioenergy development, availability of biomass resources, policy regulations and sustainability certification. Future scenarios of trade streams of biomass for energy and detailed investigation of the interplay of the various factors influencing the biomass trade could be interesting topics for future research. Additionally, future research could consider the role of agricultural products (such as oil seeds, but also other agricultural products) and indirect trade of these for energy; and the potential role on international markets of currently non-traded bioenergy products such as municipal and biomass waste.

\section{Acknowledgements}

This work was carried out for IEA Bioenergy Task 40 (Sustainable Biomass Markets and International Trade to Support the Biobased Economy) as part of the "Update Study of International Energy Biomass Trade". We would like to thank Thuy Mai-Moulin, Ric Hoefnagels, Hui Yue, Sierk de Jong, Maria Joao Ferreira Dos Santos and Li Shen from the Copernicus Institute of Sustainable Development (Utrecht University) for valuable comments. The authors would like to acknowledge members of IEA Bioenergy Task 40 for their insights into global biomass market operations. We would like to thank Peter Jones (LUT) for valuable comments. 


\section{REFERENCES}

[1] IEA, Bioenergy and biofuels. 2017. Available at: https://www.iea.org/topics/renewables/bioenergy/ [accessed 18 October 2017].

[2] WBA, the Global Bioenergy Statistics. [Online] (2016). Available at: http://www.worldbioenergy.org/content/wba-launches-global-bioenergy-statistics-2016 [accessed 27 August 2017].

[3] Heinimö J and Junginger M, Production and trading of biomass for energy - An overview of the global status. Biomass and Bioenergy 33(9):1310-1320 (2009).

[4] Heinimö J and Junginger M, Production and trading of biomass for energy - An overview of the global status. 15th European Biomass Conference and Exhibition, 7-11 May, Berlin, Germany (2007).

[5] Lamers P, Hoefnagels R, Junginger M, Hamelinck C and Faaij APC, Global solid biomass trade for energy by 2020: An assessment of potential import streams and supply costs to north-west Europe under different sustainability constraints. GCB Bioenergy 7(4):618634 (2014).

[6] Lamers P, Hamelinck C, Junginger M and Faaij APC, International bioenergy trade - a review of past developments in the liquid biofuels market. Renewable and Sustainable Energy Review 15:2655-2676 (2011).

[7] Lamers P, Hamelinck C, Junginger M and Faaij APC, International bioenergy trade - a review of past developments in the solid biofuels market. Renewable and Sustainable Energy Review 16(5):3176-3199 (2012).

[8] Goh CS, Junginger M, Cocchi M, Marchal D, Thrän D, Hennig, C et al., Wood pellet market and trade: A global perspective. Biofuels Bioprod Bioref 7:24-42 (2013).

[9] Matzenberger J, Kranzl L, Tromborg E, Junginger M, Daioglou V, Goh CS et al., Future perspectives of international bioenergy trade. Renewable and Sustainable Energy Review 43:926-941 (2015).

[10] Goh CS, Junginger M and Faaij APC, Monitoring sustainable biomass flows: General methodology development. Biofuels Bioprod Bioref 8:83-102 (2014).

[11] Hoefnagels R, Resch G, Junginger M and Faaij APC, International and domestic uses of solid biofuels under different renewable energy support scenarios in the European Union. Applied Energy 131:139-157 (2014).

[12] Kalt G and Kranzl L, An assessment of international trade related to bioenergy use in Austria-Methodological aspects, recent developments and the relevance of indirect trade. Energy Policy 46:537-549 (2012).

[13] Trømborg E, Bolkesjø TF and Solberg B, Biomass market and trade in Norway: Status and future prospects. Biomass and Bioenergy 32:660-671 (2008).

[14] Ericsson K and Nilsson L, International biofuel trade-A study of the Swedish import. Biomass and Bioenergy 26:205-220 (2004).

[15] Proskurina S, Junginger M, Heinimö J and Vakkilainen E, Global biomass trade for energy: Part 1 - Statistical and methodological considerations. Biofuels Bioprod Bioref (in this issue).

[16] Faostat, Food and agriculture organization of the United Nations statistics division, [Online] (2015). Available at: http://faostat3.fao.org/browse/F/*/E [accessed $25 \mathrm{July}$ 2016].

[17] ITC, List of supplying markets for a product imported by country. TRADE MAP International Trade Statistics [Online] (2016). Available at: http://www.trademap.org/tradestat/Country_SelProductCountry_TS.aspx [accessed 22 July 2016].

[18] Port of Rotterdam, Europe is becoming an internal market for biodiesel, Port of Rotterdam, Port of Rotterdam [Online] (2015). Available at: 
https://www.portofrotterdam.com/en/news-and-press-releases/europe-is-becoming-aninternal-market-for-biodiesel [accessed 25 June 2016].

[19] Thrän D, Peetz D, Schaubach K, Backéus S, Benedetti L, Bruce L, et al., Global Wood Pellet Industry and Trade Study 2017. IEA Bioenergy Task 40, Sustainable biomass market and International trade to support the biobased economy. (2017).

[20] OECD, OECD-FAO agricultural outlook 2015-2024: OECD-FAO agricultural outlook 2015-2024, by commodity. OECD.stat [Online] (2016). Available at: https://stats.oecd.org/Index.aspx?DataSetCode=HIGH_AGLINK_2015 [accessed 8 December 2016].

[21] USDA, Biofuels Annual - Biofuels - Ethanol and Biodiesel - Brazil. United States Department of Agriculture - Foreign Agricultural Service [Online] (2015). Available at: https://gain.fas.usda.gov/Recent\%20GAIN\%20Publications/Biofuels\%20Annual_Sao\%2 OPaulo\%20ATO_Brazil_8-4-2015.pdf [accessed 8 December 2016].

[22] USDA, EU-28, Biofuels Annual [Online] (2017). Available at: https://gain.fas.usda.gov/Recent\%20GAIN\%20Publications/Biofuels\%20Annual_The\%2 OHague_EU-28_6-29-2016.pdf [accessed 8 December 2016].

[23] Biofuel Policy Watch, Ethanol mandates and government policies around the world [Online] (2013). Available at:

https://biofuelpolicywatch.wordpress.com/2013/01/25/ethanol-mandates-andgovernment-policies-around-the-world/ [accessed 30 November 2016].

[24] RFA, Renewable Fuels Association, Fueling a high octane future, Ethanol Industry Outlook [Online] (2016). Available at: https://www.ethanolrfa.org/wpcontent/uploads/2016/02/Ethanol-Industry-Outlook-2016.pdf [accessed 18 November 2017].

[25] EIA, total energy, fuel ethanol overview [Online]. 2016 Available at: http://www.eia.gov/totalenergy/data/browser/?tbl=T10.03\#/?f=A\&start=1981\&end=2015 \&charted=7-18 [accessed 8 January 2017].

[26] AgMRC, Agricultural Marketing Resource Center, An Overview of the Biodiesel Market: Production, Imports, Feedstocks and Profitability [Online] (2017). Available at: http://www.agmrc.org/renewable-energy/renewable-energy-climate-changereport/renewable-energy-climate-change-report/march-2016-report/an-overview-of-thebiodiesel-market-production-imports-feedstocks-and-profitability/ [accessed 18 February 2017].

[27] USDA, Gain Report, Malaysia, biofuels [Online] (2016). Available at: http://gain.fas.usda.gov/Recent\%20GAIN\%20Publications/Biofuels\%20Annual_Kuala\% 20Lumpur_Malaysia_7-27-2016.pdf [accessed 8 December 2016].

[28] Indexmuundi, Palm Oil Production by Country in 1000 MT [Online] (2017). Available at: http://www.indexmundi.com/agriculture/?commodity=palm-oil\&graph=production [last accessed 18 February 2017].

[29] Bioenergy international, Around half of EU crop-based biodiesel production is based on imports $-T \& E$ [Online] (2016). Available at: https://bioenergyinternational.com/feedstock/around-half-eu-crop-based-biodieselproduction-based-imports-says-te [accessed 18 October 2017].

[30] WWF, Brochure. The Journey Towards Sustainable Palm Oil, China [Online] (2012). Available at: http://wwf.panda.org/ [accessed 18 February 2017].

[31] Oil word, Palm oil [Online] (2017). Available at: https://www.oilworld.biz/ [accessed 18 February 2017].

[32] Proskurina S, Rimppi H, Heinimö J, Hansson J, Orlov A, Raghu K et al., Logistical, economic, environmental and regulatory conditions for future wood pellet transportation 
by sea to Europe: The case of Northwest Russian seaports. Renewable and Sustainable Energy Review 56:38-50 (2016).

[33] Proskurina S, Heinimö J, Mikkilä M and Vakkilainen E, The wood pellet business in Russia with the role of North-West Russian regions: present trends and future challenges. Renewable and Sustainable Energy Review 51:730-740 (2015).

[34] International Trade Administration, 2015 Top Markets Report Renewable Fuels. U.S. Department of Commerce - International Trade Administration, Washington [Online] (2015). Available at: http://trade.gov/topmarkets/renewable-energy.asp [accessed 11 January 2017].

[35] Proskurina S, Alakangas E, Heinimö J, Mikkilä M and Vakkilainen E, A survey analysis of the wood pellet industry in Finland: Future perspectives. Energy, 118(1):692-704 (2017).

[36] Biomassmagazine.com, Baltic Bloom [Online] (2016). Available at: http://biomassmagazine.com/articles/12763/baltic-boom [accessed 21 January 2017].

[37] Lamers P, Marchal D, Heinimö J and Steierer F, Chapter 3 Global woody biomass trade foe energy. In: Junginger M, Goh CS and Faaij APC, International bioenergy trade, History status \& outlook on securing sustainable bioenergy supply, demand and markets, 2014. Springer, the Netherlands.

[38] Biomass magazin, Asian Wood Pellet Producer \& Market Snapshot [Online] (2017). Available at: http://biomassmagazine.com/articles/13880/ [accessed 3 April 2017].

[39] Biomass magazin, South Korea, Japan wood pellet imports near records in late 2016 [Online] (2017). http://www.biomassmagazine.com/articles/14481/south-korea-japanwood-pellet-imports-near-records-in-late-2016 [accessed 7 July 2017].

[40] AEBIOM, Statistical Report - European Bioenergy Outlook 2015. AEBIOM, Brussels [Online] (2015). Available at: www.aebiom.org [accessed 10 June 2016].

[41] Alternative Fuels Data Center, Alternative fuels data center: maps and data [Online] (2014). Available at: http://www.afdc.energy.gov/data/ [accessed 24 June 2016].

[42] Ethanol producer magazine, The latest news and data about ethanol production [Online] (2016). Available at: http://www.ethanolproducer.com/articles/8323/by-train-by-truck-orby-boat [accessed 30 June 2016].

[43] Transport and Environment, Cars and trucks burn almost half palm oil used in Europe [Online] (2016). Available at: https://www.transportenvironment.org/sites/te/files/publications/2016_05_TE_EU_veget able_oil_biodiesel_market_FINAL_0.pdf [accessed 30 June 2016].

[44] European commission, Trade, Anti-damping [Online] (2014). Available at: http://ec.europa.eu/trade/policy/accessing-markets/trade-defence/actions-against-importsinto-the-eu/anti-dumping/ [accessed 30 November 2016].

[45] Dafnomilis I, Hoefnagels R, Pratama YW, Schott DL, Lodewijks G and Junginger M, Review of solid and liquid biofuel demand and supply in Northwest Europe towards 2030 - A comparison of national and regional projections. Renewable and Sustainable Energy Reviews 78:31-45 (2017).

[46] Kurnia JC, Jangam SV, Akhtar S, Sasmito AP and Mujumdar AS, Advances in biofuel production from oil palm and palm oil processing wastes: a review. Biofuel Research Journal 9:332-346 (2016).

[47] Certified sustainable palm oil. Where is palm oil grown? [Online] (2016). Available at: http://greenpalm.org/about-palm-oil/where-is-palm-oil-grown-2 [accessed 18 January 2017].

[48] Schleifer F, Private governance undermined: India and the Roundtable on sustainable palm oil. Global Environmental politics 16(1):38-58 (2016). 
[49] NEA, Rapportage Energie voor Vervoer in Nederland 2016 (In Dutch). (Report of energy for transport in the Netherlands 2016) [Online] (2016). Available at: https://www.emissieautoriteit.nl/onderwerpen/rapportages-en-cijfersev/inhoud/totaalrapportages [accessed 18 February 2017].

[50] BLE, Federal Office for Agriculture and Food, Evaluations- und Erfahrungsbericht für das Jahr 2015. Biomassestrom-Nachhaltigkeitsverordnung BiokraftstoffNachhaltigkeitsverordnung, (In German) (Evaluation and Experience Report for 2015. Biomass Electricity Sustainability Ordinance Biofuel Sustainability Ordinance). (2015). [accessed 18 February 2017].

[51] Sun C, Competition of wood products with different fiber transformation and import sources. Forest Policy and Economics 74:30-39 (2017).

[52] Wild M, Deutmeyer M, Bradley D, Hektor B, Hess JR, Nikolaisen L et al., Possible effects of torrefaction on biomass trade. IEA Bioenergy Task 40, Sustainable biomass markets and international trade to support the biobased economy. Paris, pp. 68 (2015).

[53] Proskurina S, Heinimö J, Schipfer F and Vakkilainen E, Biomass for industrial applications: the role of torrefaction. Renewable Energy 111:265-274 (2017).

[54] Tsoutsos TD, Tournaki S, Paraíba O and Kaminaris SD, The used cooking oil-tobiodiesel chain in Europe assessment of best practices and environmental performance. Renewable and sustainable energy reviews 54:74-83 (2016).

[55] expert oppinion from MVO - The Netherlands Oils and Fats Industry

[56] Kousoulidou $\mathrm{M}$ and Lonza $\mathrm{L}$, Biofuels in aviation: fuel demand and $\mathrm{CO}_{2}$ emissions evolution in Europe toward 2030. Transportation Research Part D: Transport and Environment 46:166-181 (2016).

[57] Mawhood R, Gazis E, de Jong S, Hoefnagels R and Slade R, Production pathways for renewable jet fuel: a review of commercialization status and future prospects. Biofuels, Bioprod. Bioref 10(4):462-484 (2016).

[58] QYR Chemical \& Material Research Center, Europe biochar industry 2016 market Research Report (2016).

[59] Sikkema R, Steiner M, Junginger M, Hiegl W, Hansen MT and Faaij APC, The European wood pellet markets: current status and prospects for 2020. Biofuels Bioprod Bioref 3:250-278 (2011).

[60] The economist, Brazilian brew, America opens up to Brazilian ethanol [Online] (2012). Available at: http://www.economist.com/node/21542431?frsc $=\mathrm{dg} \% 7 \mathrm{Ca}$ [accessed 30 June 2016].

[61] Colitt R and Nielsen S, Brazil ethanol drive falters on domestic supply shortage. Bloomberg [Online] (2012). Available at: http://www.bloomberg.com/news/articles/2012-03-13/brazil-ethanol-slows [accessed 30 June 2016].

[62] Welfle A, Balancing growing global bioenergy resource demands - Brazil's biomass potential and the availability of resource for trade. Biomass and Bioenergy 105:83-95 (2017).

[63] Comodity.com, palm oil trading \& markets [Online] (2014). Available at: http://howtotradecommodities.com/palmoil.html [accessed 11 January 2017].

[64] Union of concerned scientist, Palm oil [Online] (2016). Available at: http://www.ucsusa.org/global-warming/stop-deforestation/drivers-of-deforestation-2016palm-oil\#.WfX 5Ihx3v8 [accessed 11 January 2017].

[65] TFT, Charcoal TFT research [Online] (2015). Available at: http://www.tft-earth.org/wpcontent/uploads/2015/05/TFT-charcoal-research.pdf [accessed 8 June 2017].

[66] FAO, Food and Agriculture Organization of the United Nations, The charcoal transition greening the charcoal value chain to mitigate climate change and improve local 
livelihoods [Online] (2017). Available at: http://www.fao.org/3/a-i6935e.pdf [accessed 8 November 2017]. 